\title{
THE RELATIONSHIP BETWEEN THE MANIFESTATIONS OF MOBBING AND REACTIONS OF MOBBING VICTIMS
}

\author{
Lidia Grzesiuk ${ }^{1}$, Agnieszka Szymańska ${ }^{1}$, Justyna Jastrzębska ${ }^{1}$, Małgorzata Rutkowska² \\ ${ }^{1}$ Cardinal Stefan Wyszynski University in Warsaw, Warsaw, Poland \\ Institute of Psychology, Department of Psychotherapy \\ ${ }^{2}$ Institute of Group Analysis "Rasztów," Warsaw, Poland
}

\begin{abstract}
Background: The study concerned workplace mobbing, a phenomenon affecting about 3-20\% of the Polish population. The aim of the article is to distinguish the manifestations of mobbing, to study the coexistence of mobbing manifestations, and to search for the relationships between the symptoms of mobbing, reactions to mobbing and methods of dealing with mobbing used by victims. Material and Methods: Information on the above variables was obtained using a questionnaire on mobbing, risk factors, and responses to mobbing. The questionnaire was completed by 781 people (women: $66 \%$, men: $34 \%$ ). The average age of the respondents was 29 years. The current statistical analysis included: distinguishing the manifestations of mobbing by means of a confirmatory factor analysis, studying the coexistence of mobbing manifestations by means of a cluster analysis, and detecting the relationships between mobbing manifestations, reactions to mobbing and ways of dealing with it based on the system of structural equations. Results: The results of the research revealed 3 categories of relationships: a co-occurrence of mobbing manifestations, a relationship of mobbing manifestations with reactions to mobbing, and a relationship of mobbing reactions with methods of dealing with mobbing. Conclusions: Mobbing was found in $22 \%$ of the examined group. The study revealed the existence of 5 clusters of mobbing manifestations (i.e., subgroups of respondents characterized by experiencing at least 1 of the mobbing manifestations). In the most numerous clusters in which the symptoms of mobbing were diagnosed, unfriendly working conditions prevailed. In the context of mobbing, people were found to more often react with passivity or with using interpersonal coping methods. However, they rarely turned to institutions for help or used aggression against the mobber. Med Pr. 2022;73(1):1-12
\end{abstract}

Key words: theoretical model, structural equation model, data mining algorithms, manifestations of mobbing in the workplace, reactions to mobbing, ways of dealing with mobbing

Corresponding author: Agnieszka Szymańska, Cardinal Stefan Wyszynski University in Warsaw, Institute of Psychology, Department of Psychotherapy, Wóycickiego 1/3, 01-938 Warsaw, Poland, e-mail: agnieszka.szymanska@uksw.edu.pl

Received: April 19, 2020, accepted: October 15, 2021

\section{INTRODUCTION}

Karl Lorenz [1] first used the concept of mobbing in relation to studies on the herd behavior of various animal species conducted in the 1950s. In this context, mobbing meant a group attack of representatives of a given species on a predator posing a threat to or harassing other individuals also belonging to the same species. The author associated this term with aggression in the animal world. The term "mobbing" was transferred in the following decade to the school environment by Peter-Paul Heinemann, in order to define aggressive peer behavior, especially in the context of racial discrimination and belonging to a particular social class [2].

Until the 1980s, the concept of mobbing in the workplace did not function in literature. This changed due to Leymann [3] who wrote about the functioning of people in the work environment and employee relations.
Over time, he came to the conclusion that there were certain characteristic long-lasting behavioral patterns of aggression manifestation in the workplace, not necessarily expressed in a direct way, in relation to an employee or a group. Based on the results of extensive research carried out at Swedish workplaces, Leymann created an operational definition of the concept. He referred to mobbing as "hostility and unethical communication, which is systematically directed by 1 or several people, mainly towards 1 person [...]. These activities take place frequently (almost every day) and for a long period (at least 6 months), and because of this frequency and duration, they lead to mental and psychophysical cachexia." It is the durability and frequency - the characteristics of mobbing - that make it strongly affect the victim. As Ovid said, "a drop drills the rock not with force but by perseverance." Leymann's definition became the basis for the subsequent research 
on this subject and was further developed by other researchers $[4,5]$.

The studies on mobbing in the workplace described in literature refer to the frequency of its occurrence, risk factors, and consequences.

The information cited in American literature suggests that the incidence of mobbing in the workplace ranges about 28-36\% [6-8]. Research conducted in Europe indicates that mobbing affects about $8-9 \%$ of employees, while in Poland the figure is about $3-20 \%$, depending on the employment sector [9]. A report on the psychosocial hazards at work created by the World Health Organization points to the fact that mobbing, violence, and harassment are widespread workplace phenomena [10]. Similar conclusions were reached by the author of the Gdańsk District Labor Inspectorate report [11], where interpersonal relations were indicated as a stressful factor and mobbing was asserted to be one of the most important and most destructive stressors in the workplace.

Data of the National Labor Inspectorate indicate a 10 -fold increase in the number of complaints regarding mobbing in 2005-2012 [12]. The authors state that these data may be incomplete, and many experienced events that meet the criteria for mobbing are not reported by the victims. It may be related to the public belief that "it is better to have a boss - a tyrant - than not to have any" [13], and also, with a high level of unemployment, to low chances of changing jobs, ignorance of the Labor Code, employment without a contract, or reluctance to be the one to report colleagues' misbehavior [14]. Mobbing is "one of the most acute social issues" and a problem affecting a large part of the population, although the awareness of its occurrence was for many years low [15].

There is no agreement in literature about the etiology of mobbing. Among the causal factors, the following are mentioned: the economic situation, improper communication in the work environment, management system and work environment rules, personality traits, exposure to stressful situations, the need to embed an individual in the structure of an organization, competition among employees, the abuse of power, and a lack of social skills and competence on the part of the supervisor, or his/her low self-esteem [16]. This is in line with the opinion expressed by Leymann [3], who emphasized the importance of disturbing relations between employees, e.g., because of jealousy, aversion, or prejudice, which may contribute to the occurrence of mobbing. It may also be related to the desire to gain an advantage and control over the victim, ineffective defenses against the mobber, or the fact that the victim is unable to defend him-/herself against the mobber $[3,17]$.

This article is devoted to the analysis of the relationship between the manifestations of mobbing and victim reactions to mobbing. Admittedly, some research is presented in literature on the relationship between mobbing and victim reactions. However, in these studies, no manifestations of mobbing are distinguished. As a consequence, mobbing is conceptualized as a binary, all-ornothing occurrence. This research intends to fill this gap.

\section{Mobbing manifestations}

Leymann [3] mentioned 5 categories of events with features of mobbing at work, which provided the basis for the subsequent reflections on the ethical side of events and behaviors occurring at the workplace. These are:

- destroying reputation - denigration, ridicule, rumors,

impeded communication - direct criticism, making it impossible to speak,

social isolation,

obstructing work or entrusting senseless and humiliating tasks, and

threats and violence.

Leymann's proposal is the basis for other authors describing the manifestations of mobbing, in whose works, despite some differences in the terms used, an analogy to the division featuring a description of a similar spectrum of mobber behavior, as proposed by Leymann, can be seen. The author stated that the categorization which he proposed focused on deductive inference, based on interviews with employees of companies who had experienced negative events in the work environment, conducted at the initial stage of developing a questionnaire to study the effects of mobbing [3]. On this basis, the symptoms of mobbing at the place of employment were described. The author himself remarked that the created categorization was the result of research work carried out in order to identify changes taking place in the functioning of people subjected to mobbing in the mental, social and somatic areas.

Some authors point to the arbitrary nature of the categorization of mobbing manifestations proposed by Leymann and to the overarching goal of his research, i.e., identifying the relationship between this phenomenon and negative changes in the functioning of victims. They also draw attention to the possible imprecision of the image of this phenomenon [17]. The literature on the subject postulates the need to expand the scope of possible mobber behaviors and further verification, especially at 
the empirical level, of the models existing in literature and the search for new dependencies [5]. In the literature on mobbing, some categorizations further developing Leymann's proposal are described [4]. Introducing them to the literature on the subject was the result of further searches for possible manifestations of mobbing and types of mobber behaviors.

The literature on the subject indicates that mobbing is a heterogeneous phenomenon, complex in terms of possible mobber behaviors, their frequency and intensity, and difficult to recognize. Due to the large scale of possible determining factors, depending on the research goals and the assumptions adopted by the researchers, the results obtained in terms of categorizing this phenomenon may be diverse [17]. The differentiation of the categorization of mobbing manifestations, as appearing in literature, may be the result of the researchers' commitment to taking into account, in particular, the criteria of its occurrence, while disregarding the significance of its possible manifestations [15].

For the purpose of this study, 5 categories of mobbing manifestations were distinguished by modifying Leymann's views, which were then systematized "so that they would be closer to the behavioral level and thus become more unambiguous and separable" [18]. The adopted categorization of mobbing manifestations results from the empirical data obtained in questionnaire studies, relating to Leymann's categorization, with the simultaneous extension of the range of possible experiences of a person subjected to mobbing at the behavioral level [18]. The analyzes of the obtained results confirmed the existence of 5 categories of mobbing in the workplace.

The following mobber behaviors were distinguished: using psychological terror,

ignoring the victim,

creating unfriendly working conditions,

sexual harassment,

physical violence.

Behavioral indicators were as follows:

Psychological terror, as used in the survey, considered such mobber behavior as preventing the victim from speaking, mocking their opinions, threatening them, spreading gossip about them, suggesting or implying a mental illness on their part, using offensive terms, shouting at them, or expressing contempt for their personal life, education, and so forth. Ignoring the victim was understood as comprising such activities as disregarding the victim, forbidding them from having conversations with employees, or isolating them in the workplace.
The creation of unfriendly working conditions involved, among others, assigning the victim tasks that were inadequate to their skill, excessive control of their work performance, undermining their competence or their efforts at receiving bonuses, or forcing them to spend additional hours at work.

Sexual harassment included such mobber behaviors as referring to the victim with comments with sexual undertones, intrusive gazing, touching intimate areas of their body, forcing sexual intercourse or even rape.

Physical abuse was characterized by threatening injury, taking things belonging to the victim, assigning them tasks harmful to their health, and expressing aggression through direct physical contact - e.g., by pushing, jerking.

Mobbing was diagnosed when a person experienced at least 1 of its distinguished manifestations meeting the following 2 criteria:

1) a duration of at least 6 months, and

2) a frequency of at least once a week.

\section{Victim's reactions to mobbing}

Researchers agree that experiencing this phenomenon causes negative reactions (in the literature on this subject, this variable is also referred to as the consequences of mobbing or the effects of mobbing), among others, of lower self-esteem, problems with concentration and memory, feelings of frustration, sadness, a lack of purpose of one's work, and anger, as well as a possible development of depression, anxiety disorders, addiction, mental destabilization, nervous breakdown, and post-traumatic stress disorder. It may even lead to a suicide attempt $[11,12,19]$. In addition, the victim of mobbing, struggling with the tension and stress accompanying him/her in the workplace, may experience deterioration in social functioning and exhaustion. As a consequence, it may bring about a sense of failure and professional burnout $[18,20]$. The person experiencing mobbing may also develop learned helplessness and the conviction that no attempt to change the situation will have any effect. Mobbing is, therefore, a serious problem. It may have an effect of deteriorating the victim's psycho-physiological and social functioning.

Mobbing is a phenomenon experienced subjectively, which is why the behavior of victims and their functioning in relation to the mobbers' actions are of individual character and can have a varying form.

Literature also draws attention to certain somatic symptoms that may occur in response to experienced 
events. Victims of mobbing may have problems with the functioning of their circulatory system (e.g., an increased risk of a heart attack, ischemic heart disease), the digestive system (diarrhea, peptic ulcer disease, etc.), somatic pain, insomnia, decreased immunity, or frequent infections $[11,19,21]$.

Victims also report problems with cognitive functioning, distraction or a lack of concentration, as well as experiencing prolonged negative emotional states, such as feelings of helplessness, deterioration of mood, anger, anxiety, or a constant sense of insecurity. Mobbing is, therefore, a threat to the basic needs of a person, who ceases to feel safe in the environment, which - paradoxically - should provide him/her with a sense of stability [21].

The victim's situation forces him/her to undertake some behavior in response to the mobber's actions. This behavior can assume a passive or active form [22].

Actively coping with mobbing can be manifested through actions taken to solve the problem. Such activities include starting a dialogue with the mobber and requesting him/her to cease acting in such a way [21]. In the absence of a reaction from the mobber, it may seem reasonable to try to inform the supervisor, colleagues, or trade unions and officials dealing with workplace quality control of the experienced mobbing. In addition, the victim may try to get materials, such as recording conversations, in order to prove his/her case.

Some authors believe that the most effective active measure that the victim can apply is changing the workplace. Often, however, the material situation of the victim as well as the economic reality make it impossible to make such a decision. In some cases, separating oneself from the mobber and changing the environment is the most advantageous of the possible options if other actions have not produced results. Research results indicate that up to one-fourth of people experiencing mobbing may consider leaving the workplace [23]. Mobbing is one of the main reasons for the termination of employment contracts in Poland, as indicated by Piątkowska [24]. Additionally, among people who experience it and who have decided not to leave the workplace, mobbing can cause a significant increase in sickness absence.

A passive reaction to mobbing occurs when the victim tries to avoid thinking about the experienced events of confrontation with the mobber. It may be related to the desire to literally escape from the problem [22]. Victims may try to cope with mobbing through drug and alcohol use, smoking, or overeating [25].

For a small group of people, experiencing mobbing may have short-term positive effects, such as, for example, general mobilization and increased involvement in the performance of duties [18].

Based on the results of research carried out in 20032008 , the following groups of victim responses to mobbing were identified:

- emotional reactions (negative, positive),

non-specific somatic reactions,

behavioral reactions (negative, positive), and

- cognitive reactions (positive, negative) [18].

Two types of coping with mobbing were also distinguished, i.e.,

constructive (interpersonal, institutional) and

unconstructive (passive, aggressive).

Constructive coping methods include expressing objections to the mobber's actions and seeking interpersonal (from other people, e.g., family, colleagues) or institutional (referring to institutions, e.g., government organizations dealing with employment issues) help. In turn, unconstructive ways can be observed when the victim ignores the experienced annoyances, turns the existing situation into a joke or "joins the game."

\section{Research on the relationship between mobbing manifestations and mobbing reactions}

Research on mobbing examining the factors determining the functioning of its victim, mostly concerns the effects of experiencing this phenomenon, understood in binary terms of all-or-nothing categories. Namely, it focuses on whether mobbing occurs or not. However, such research does not take into account what kinds of mobber's actions prompt the victim to react in a certain way. The results of these studies have been indicated above $[11,19,21-23,26]$. Therefore, these works provide information about the relationship between the occurrence and non-occurrence of mobbing, and reactions to these situations.

The authors have not found any research on the relationship between the specific manifestations of mobbing and reactions to these manifestations. The necessity to conduct research in this area, for a fuller understanding of this phenomenon, and the lack of literature describing the relationships between these variables is emphasized by Einarsen and Mikkelsen [27]. One of the objectives of this research was to try to fill this gap by examining the interdependencies between the manifestations of mobbing - not as in the current literature the occurrence of the mobbing - and the victim's reactions to these behaviors $[11,19,21-23,26]$.

This research served the implementation of 3 research objectives. The first goal was to distinguish 


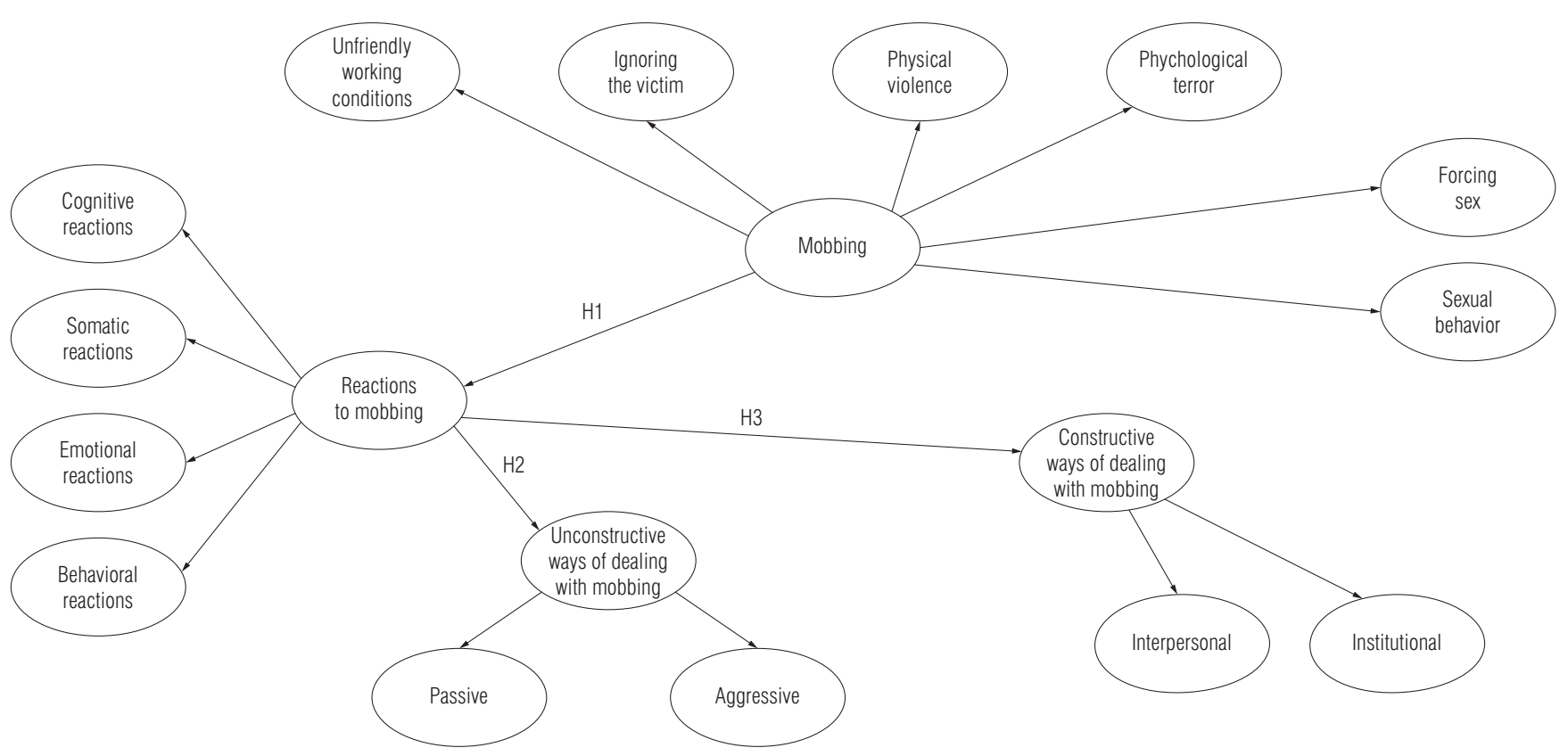

Figure 1. A model presenting the relationship between the manifestations of mobbing and the reactions to mobbing, and ways of dealing with mobbing

the mobbing manifestations; for this purpose, the authors used a confirmatory factor analysis. The next goal was to determine the coexistence of 5 isolated mobbing manifestations (using a cluster analysis), and the third objective of the research was to verify mutual relations in the following areas:

mobbing manifestations: (1.1) unfriendly working conditions, (1.2) ignoring the victim, (1.3) psychological terror, (1.4) physical violence, and (1.5) sexual harassment,

reactions to mobbing: (2.1) cognitive reactions, (2.2) somatic reactions, (2.3) emotional reactions, and (2.4) behavioral reactions,

ways of dealing with mobbing, i.e., (3.1) unconstructive (passive and aggressive), and (3.2) constructive (interpersonal and institutional).

On the basis of work by Grzesiuk [18], presenting the concept of mobbing and the results of empirical research in this field, a theoretical model describing the relationships between the mobbing manifestations and reactions to mobbing was developed (Figure 1). It served as the basis for formulating the 4 research hypotheses in this study presented below as: $\mathrm{H} 1, \mathrm{H} 2, \mathrm{H} 3$ and $\mathrm{H} 4$.

The letter $\mathrm{H}$ denotes the relationships in the model to which a given hypothesis relates.

$\mathrm{H} 1$ : There is a positive relationship between the mobbing manifestations and the reactions to mobbing. In those respondents for whom the criteria for experiencing mobbing were met, its specific manifestations remain in a significant, positive relationship with specific reactions at the behavioral, emotional, cognitive or somatic levels.

$\mathrm{H} 2$ : There is a positive relationship between the reactions to mobbing and the unconstructive ways of dealing with mobbing. Specific behaviors undertaken by a victim of mobbing in response to his/her experience are positively related to unconstructive ways of coping, which may take diversified forms and involve a spectrum of activities, characterized by passivity or aggression.

H3: There is a negative relationship between the reaction to mobbing and the constructive ways of dealing with mobbing. Victims' actions taken in response to mobber behaviors are negatively related to constructive coping methods, such as taking specific actions in an interpersonal or institutional context.

H4: The (1) manifestations of mobbing: (1.1) unfriendly working conditions, (1.2) ignoring the victim, (1.3) psychological terror, (1.4) physical violence, and (1.5) sexual harassment co-occur with (2) reactions to mobbing: (2.1) cognitive reactions, (2.2) somatic reactions, (2.3) emotional reactions, (2.4) behavioral reactions and (3) unconstructive and constructive ways of dealing with mobbing. The individual categories of mobber behaviors are related to the occurrence of specific reactions and behaviors of the victims and the use of specific ways of dealing with negative experiences in the workplace. 


\section{MATERIAL AND METHODS}

\section{Research sample}

Seven hundred and eighty-one people participated in the study. The selection of the respondents was random, dictated by organizational reasons; they were students (including extramural and postgraduate students) with professional experience. Characteristics of the research participants were as follows:

in the sample, there were 512 women (66\%) and 269 men (34\%);

- the mean age of the participants was 29 years, the age of the respondents ranged 18-63 years; the age range of most respondents (51\%) was 18-25 years;

as for education, $25.5 \%$ of the respondents had a university degree, $2 \%$ had a doctoral degree, $62 \%$ were students, and $12 \%$ had secondary or college education;

- the vast majority (47\%) of the respondents came from large cities with populations $>300000$ residents; $35 \%$ of the examined sample came from smaller cities and towns, while $18 \%$ of the respondents lived in the countryside;

as regards the distinction into private and public sectors, $68 \%$ of the tested sample worked in private companies, and $26 \%$ were public servants;

- in terms of the employment sector, $33 \%$ of the respondents worked in the service industry, 19\% in the commercial sector, $9 \%$ in education services; $9 \%$ in public administration, $5 \%$ in industry, $4 \%$ in healthcare services, and $2 \%$ in the medical services; as regards employment by sex, $41 \%$ of the respondents worked in companies employing the same number of men and women, 34\% worked mostly or only with women, and $21 \%$ mostly or only with men; in terms of the enterprise size, $41 \%$ of the respondents worked in small companies employing $\leq 30$ people, $56 \%$ in companies employing $>30$ people $(21.1 \%$ of the respondents worked in companies employing $\leq 10$ people; $21.4 \%$ of the respondents in companies employing $11-30$ people; $17 \%$ in companies employing $31-100$ people, and $40.3 \%$ in corporations employing $>100$ people);

on average, the respondents had 6.8 years of work experience, of which they worked in the previous company, on average, for 3.7 years;

only $2.7 \%$ of people in the surveyed sample had a work experience of $<6$ months;

at the time of the study, $93 \%$ of the respondents were professionally active, i.e., they worked in a company.
Thus, the research results characterize mainly young white-collar workers with higher education, living in large cities. Most of them combine work and university studies, and have a relatively short work experience. The results obtained cannot be generalized to the entire population of Polish employees due to the incidental selection of the subjects and the characteristics of the subgroup being investigated, e.g., the percentage ratio of women and men deviating from the overall sex ratio in society, the average age and education [18].

\section{Variable measurement and research procedure}

To measure the variables described above, a questionnaire was used, which is described in more detail in the work by Grzesiuk [18]. The original version of the survey was developed during a Master's seminar conducted by Prof. L. Grzesiuk [18] at the School of Commerce and Law (Lazarski University). The co-authors of the version used in this study were Daniel Bąk, Dagmara Kaczmarek, Marta Karpińska, Anna Kisielewska, Anna Lisowska Daria Matkowska, Marta Matuszewska, Małgorzata Rutkowska, and Kamila Sokolik, Master's students of Prof. Lidia Grzesiuk at the Faculty of Psychology of the University of Warsaw.

The questionnaire consisted of 64 test items expressed in 2 response formats: binary and a 4-point Likert scale. The questionnaire was divided into 4 parts:

1. It referred to the events describing 5 forms of mobbing (psychological terror, unfriendly working conditions, ignoring, sexual harassment and physical violence), their duration and frequency of mobbing behaviors, and the way of dealing with mobbing (56 items).

2. It concerned 4 types of reactions to mobbing - emotional, non-specific somatic, behavioral and cognitive (4 items).

3. It contained 2 questions - whether the respondent was a witness and/or a perpetrator of mobbing ( 2 items).

4. It inquired about who the perpetrator of the respondent's experience of mobbing was and what could have been its motives ( 2 items).

During the operationalization of the mobbing measurement tool, Leymann's theory describing the manifestations of mobbing was used. When creating this tool, the following were also used:

questionnaires developed by Strauss and Espeland [28],

the Polish General Social Survey containing a cumulative data structure from 1992-1994, developed by the Institute of Social Studies of the University of Warsaw, 
a survey on sexual behavior during adolescence and family life, created by Piotr Kemrałowski to measure sexual violence,

a questionnaire on problems occurring in the workplace, prepared by the Institute of Sociology of the University of Wrocław.

The reliability for the individual scales of the questionnaire ranged 0.6-0.8 (measured with Cronbach's $\alpha$ ). This reliability is sufficient to conduct scientific research.

Three of the 11 parts of this questionnaire were used, diagnosing:

- 5 manifestations of mobbing,

4 reactions to mobbing,

2 ways of dealing with mobbing.

In the survey, 4 categories of reactions to mobbing were distinguished: (1) emotional, (2) somatic, (3) behavioral, and (4) cognitive [15]. In the present study, these categories were tested by means of a confirmatory factor analysis (the values of $\lambda$ are given in the subsection on the theoretical model verification - structural equation modeling results).

The survey distinguished 2 ways of dealing with mobbing, i.e., constructive (interpersonal and institutional) and unconstructive (passive and aggressive). The results obtained by means of a confirmatory factor analysis confirmed the existence of these 4 ways of dealing with mobbing, i.e., interpersonal, institutional, passive, and aggressive (the $\beta$ values are given in the subsection on the theoretical model verification - structural equation modeling results). This indicates that each of these coping methods should be treated as separate. Table 1 includes examples of survey items.

\section{Statistical data analysis methods}

The study employed a cluster analysis carried out using data mining algorithms [29]. This is an exploratory method, using mathematical algorithms to search for existing dependencies in data sets. In the cluster analysis method, people are grouped according to the variables analyzed in the study. The algorithms group people who have similar results into 1 cluster. At the same time, this classification yields the greatest possible differences between clusters. Namely, the algorithms classify the subjects in a way that makes them as similar as possible within clusters (small intra-group variance) and as different as possible between the clusters (large intergroup variance). Thanks to this method, the number of subjects assigned to each cluster is determined. This makes it possible to determine which cluster occurs the most frequently in a given sample. The results of clustering are shown using a profile-like graph. Therefore, according to Szymańska [29], the interpretation of the cluster analysis is made not only by (1) comparing the difference between the clusters, but also by (2) describing the relationships between the variables within a given profile/cluster.

The first research objective was implemented using the cluster analysis method. The second research goal involved using the structural equation modeling [30]. Its purpose was to determine (1) whether the theoretical model describing the relationships between the variables is matched to the data obtained in the study, and (2) how strong the relationships between the variables described in the model are. The construction of the structural model was preceded by the construction of the measurement model, which was done using a confirmatory factor analysis [31].

\section{RESULTS}

\section{The most frequent mobbing manifestation co-occurrences - cluster analysis results}

Each examined person was given a diagnostic value of 1 if he/she experienced mobbing at least once a week and for at least 6 months, or 0 if their experiences did not meet these criteria, i.e., if mobbing did not occur at all or was experienced less frequently and for a shorter period of time. This diagnosis was made for each of the 5 manifestations of mobbing separately.

The group diagnosed with mobbing accounted for $21 \%(\mathrm{~N}=169)$ of the test sample.

In the subgroup of people diagnosed with mobbing (meeting both criteria of mobbing):

- unfriendly working conditions were the only manifestation of mobbing experienced by 51 subjects, while in 65 people this symptom of mobbing coexisted with other experienced manifestations of mobbing,

- psychological terror as a single manifestation was diagnosed in 9 people, whereas it occurred in the configuration with other manifestations in 35 people,

physical violence as a single manifestation was experienced by 4 people, while in 32 people it was in a configuration with other manifestations,

ignoring as a single manifestation was experienced by 3 people, while it occurred in the configuration with other manifestations in 24 people,

sexual harassment as a single manifestation of mobbing was experienced by 33 people, while it was diagnosed in a configuration with other manifestations in 20 subjects. 
Table 1. Examples of survey items related to the variables used in the research (781 subjects, Warsaw, 2007-2008)

\begin{tabular}{|c|c|c|}
\hline Variable & Category & Examples of survey items \\
\hline Manifestations of mobbing & $\begin{array}{l}\text { physical violence } \\
\text { unfriendly working conditions } \\
\text { sexual harassment } \\
\text { ignoring the victim } \\
\text { psychological terror }\end{array}$ & $\begin{array}{l}\text { "I was assigned work harmful to my health, not belonging to my duties." } \\
\text { "I was pushed, pulled, and struggled." } \\
\text { "I was given an excessive number of tasks." } \\
\text { "They undermined my competences." } \\
\text { "Comments were made, along with jokes with sexual undertones." } \\
\text { "I was touched under any pretext, as if by chance." } \\
\text { "My workplace was isolated from other employees, e.g., arranged in the other end } \\
\text { of the room or in a separate room." } \\
\text { "Employees were forbidden to contact me." } \\
\text { "I was threatened with, e.g., losing my job and ruining my career." } \\
\text { "I was ridiculed for my views, sexual orientation, my way of being, etc." }\end{array}$ \\
\hline Reactions to mobbing & $\begin{array}{l}\text { cognitive reaction } \\
\text { somatic reaction } \\
\text { emotional reaction } \\
\text { behavioral reactions }\end{array}$ & $\begin{array}{l}\text { "I could not focus." } \\
\text { "My thought was slower than usual." } \\
\text { "All the time I forgot about something." } \\
\text { "I felt tired." } \\
\text { "I had trouble falling asleep/I often woke up at night." } \\
\text { "I had stomach problems (diarrhea, abdominal pain, nausea, vomiting, etc.)." } \\
\text { "I worked under a lot of tension." } \\
\text { "I felt anger/rage/hatred." } \\
\text { "I felt it was my fault." } \\
\text { "I smoked more cigarettes." } \\
\text { "I made more mistakes at work." } \\
\text { "I was taking sick leave." }\end{array}$ \\
\hline Ways to deal with mobbing & $\begin{array}{l}\text { passive ways of coping } \\
\text { aggressive coping methods } \\
\text { interpersonal ways of coping } \\
\text { institutional ways of coping }\end{array}$ & $\begin{array}{l}\text { "I avoided the perpetrator of these events." } \\
\text { "I tried not to pay attention to me." } \\
\text { "I used physical force against the perpetrator of these events." } \\
\text { "I told the perpetrator that I did not agree to such treatment." } \\
\text { "I asked my colleague for help." } \\
\text { "I asked someone from my family/partner/friend for help." } \\
\text { "I applied to an institution helping people persecuted at work." } \\
\text { "I have brought the case to court." }\end{array}$ \\
\hline
\end{tabular}

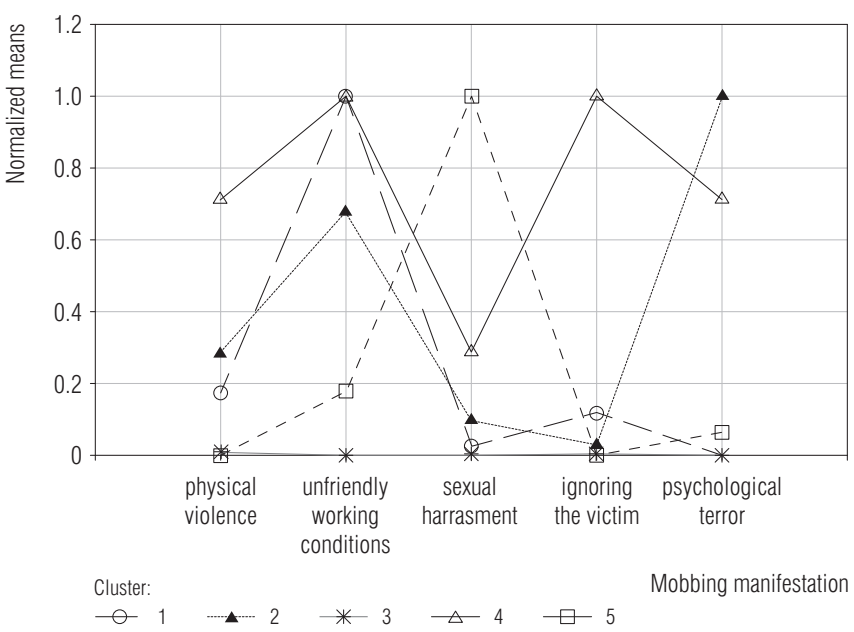

Figure 2. Cluster analysis results concerning the co-occurrence of mobbing manifestations

In the next step, data on the manifestations of mobbing were subjected to a cluster analysis with the aim of determining their co-occurrence. The results of the cluster analysis are presented in Figure 2. Five clusters describing the co-occurrence of separate mobbing manifestations have been identified.

Cluster 3, which included $79 \%$ of the subjects who did not experience any of the 5 mobbing manifestations, was represented the most often in the data set, i.e., where the 2 criteria for the diagnosis of mobbing (i.e., the criterion of sustainability and frequency) were not met.

The next cluster in terms of frequency was cluster 1, comprising $9 \%$ of the tested sample. People belonging to this cluster were diagnosed as experiencing unfriendly working conditions, which for a small number of the people in this cluster was accompanied by physical violence and by being ignored. No people with a diagnosis of experiencing psychological terror or sexual harassment were present in cluster 1 .

The third most frequently occurring cluster was cluster 5 . It comprised $6 \%$ of the tested sample. The experience of sexual harassment was characteristic of this cluster.

Cluster 2 was the fourth most frequent cluster. It included $4 \%$ of the tested sample. It was characterized by the experience of psychological terror, which was 
Table 2. Analysis of variance results for cluster differences in mobbing manifestations (781 subjects, Warsaw, 2007-2008)

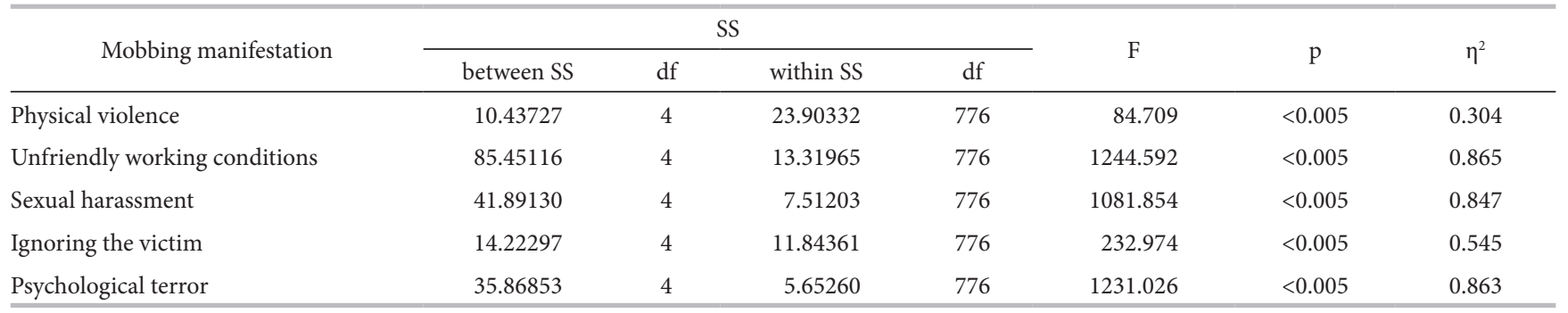

SS - sum of squares.

mainly accompanied by unfriendly working conditions and, to a lesser extent, by physical violence.

The least frequently occurring cluster, comprising only $2 \%$ of the tested sample, was cluster 4 . It was characterized by the experience of all manifestations of mobbing, chiefly of unfriendly working conditions and ignoring the victim, as well as of physical violence and psychological terror and, though in a smaller number of people in this cluster, of sexual harassment.

There were statistically significant differences between all clusters (Table 2). This means that the people inside the clusters were similar to each other and, at the same time, significantly different from people in other clusters.

\section{Relations between mobbing manifestations, mobbing reactions, and coping with mobbing - structural equation modeling results}

The theoretical model was tested using the structural equation modeling (3.2.2), which was preceded by the construction of the measurement model (3.2.1).

\section{Measurement model}

The first stage of testing the theoretical model with the use of the structural equation modeling was to verify, by means of a confirmatory factor analysis, the correctness of the so-called measurement model [31].

The results of the confirmatory factor analysis revealed the existence of 6 mobbing manifestations: unfriendly working conditions $(\lambda=0.86)$, ignoring the victim $(\lambda=0.90)$, physical violence $(\lambda=0.64)$, psychological terror $(\lambda=0.89)$, and 2 manifestations in the sexual sphere: forcing sex (including rape) $(\lambda=0.19)$ and sexual behavior (e.g., patting the victim, jokes about sex, etc.) $(\lambda=0.34)$.

The reaction variable consisted of 4 factors, with the following factor loadings: cognitive reaction $(\lambda=0.99)$, somatic reaction $(\lambda=0.92)$, emotional reaction $(\lambda=0.90)$, and behavioral reaction $(\lambda=0.76)$. The relationship was thus explained at a moderate level by the variable of mobbing. These high factor loadings indicate the co-occurrence of 4 separate reactions to mobbing.

The results of the factor analysis revealed that the methods of coping with mobbing are independent variables that cannot be reduced to the superior structure, which is dealing with mobbing.

Based on the results obtained in the measurement model, it should be noted that the variables in the model were well constructed: $\chi^{2}(840)=2875.532, \mathrm{p}<0.005$, RMSEA $=0.056$. Thus, it was possible to proceed to the second stage of testing the model using the structural equation modeling.

\section{Theoretical model verification -} structural equation modeling results The correctness of the theoretical model was tested using the structural equation modeling (Figure 3 ). The theoretical model was proven to fit the data well: $\chi^{2}(850)=2907.11, \mathrm{p}<0.005$, RMSEA $=0.056$.

The calculated value of the relationship between mobbing and the reactions to mobbing was $\beta=0.52$, $\mathrm{p}<0.005$. It is explained at a moderate level by a variable manifestation of mobbing.

The results of the structural model also revealed that the 4 ways of dealing with mobbing, i.e., passive, aggressive, interpersonal, and institutional, are mutually independent (they do not form a hierarchical structure of the constructive and unconstructive methods). The relationship between reactions to mobbing and the methods of coping with mobbing is illustrated in Figure 3. Reactions to mobbing were most strongly connected with (1) an interpersonal way of dealing with mobbing, $\beta=0.52, p<0.005$, and (2) with a passive way of dealing with mobbing, $\beta=0.47, \mathrm{p}<0.005$. Reactions to mobbing were the weakest for (1) the aggressive way of dealing with mobbing, $\beta=0.18, p<0.005$, and (2) the institutional coping method, $\beta=0.18, \mathrm{p}<0.005$. 


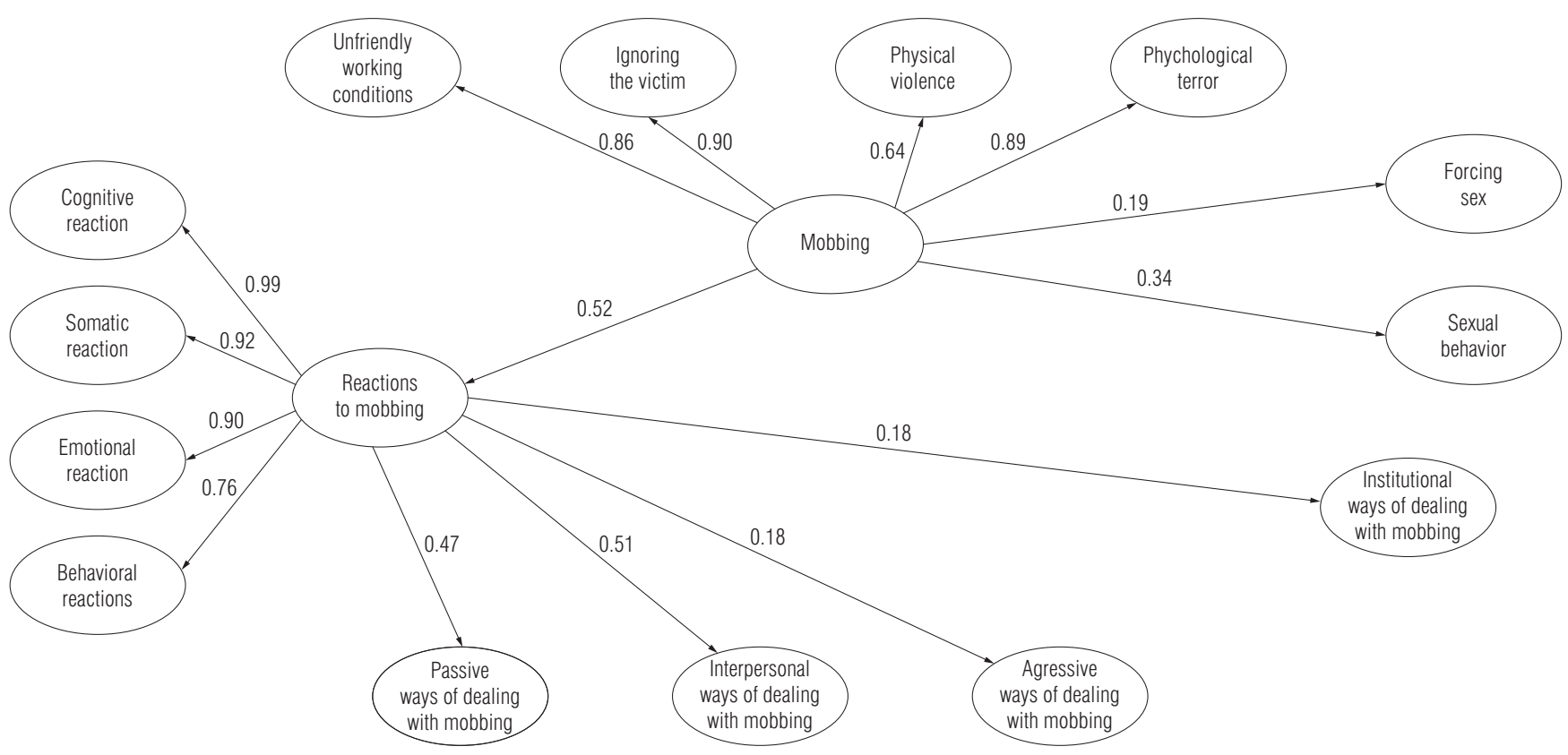

Figure 3. Results of the system of structural equations testing the theoretical model

\section{DISCUSSION}

The obtained results confirmed that, in the tested sample, mobbing occurred in about $21 \%$ of the respondents. This is the upper value described by other authors [9]. Current research conducted in Poland indicates a high level of experience of mobbing compared to other European countries [32,33]. The high level of mobbing in the workplace may result from a lack of knowledge about the phenomenon itself among employees and possible manifestations of mobbing, as well as insufficient protection of the employee in the legal context.

In the present study, it was found that the most common mobbing manifestation is unfriendly working conditions, and ignoring the victim was the least frequent. The use of a cluster analysis made it possible to determine which symptoms of mobbing co-occurred. Four combinations of mobbing manifestations appearing in the data set were reconstructed, yielding a possible number of 120 , given by the 5-element system.

The largest cluster of people with the diagnosis of mobbing was the subgroup of respondents experiencing unfriendly working conditions, physical violence, and being ignored. The experience of another group of respondents was marked by a combination of sexual harassment with unfriendly working conditions and psychological terror. The third cluster consisted of the respondents experiencing psychological terror accompanied by unfriendly working conditions and, to a lesser extent, by physical violence and sexual harassment. The fourth smallest cluster of the respondents included those who experienced all of the mobbing manifestations, with unfriendly working conditions and ignoring being the most pervasive.

It has been noticed that ignoring the victim never appears as a separate manifestation or as a dominant one in some combination. It is always accompanied by other manifestations of mobbing. In other words, a person complaining about being treated "like being invisible" also experiences other nagging mobbing symptoms.

The results revealed that the reactions to mobbing occur at the cognitive, emotional, somatic, and behavioral levels. The obtained results are consistent with those described in both Polish and global literature about changes in the victim's functioning and reactions to experiencing mobbing $[4,8,10,15,17-19]$.

The prediction regarding the separate ways of coping with mobbing, classified as constructive and unconstructive, was not confirmed [18]. In the context of mobbing, victims coped using both methods. Similar results, proving that victims undertake various activities usually categorized as passive behaviors (e.g., avoiding the mobber, the use of sick leaves) and active behaviors (e.g., an attempt to reach an agreement with the mobber), were obtained by other researchers $[8,19]$.

The most common constructive method used by the respondents are interpersonal coping methods. Passive, unconstructive coping methods were often used as well. The research revealed that constructive coping, i.e., seeking the help of an institution, was rarely used in the context of 
mobbing. Victims rarely react aggressively. In other words, subordination, enduring a difficult situation, avoiding conflict, calm and passive tolerance and/or asking relatives for help, and even appealing to the mobber were used the most often. Adequate results were obtained by Zapf and Einarsen [5]. The results described by them proved that mobbing victims rarely chose direct confrontation with the mobber, instead trying to avoid direct contact with him/her and focusing on activities unrelated to the need to recall negative thoughts associated with mobbing.

The results showed that the relationship between experiencing mobbing and looking for institutional support or self-defense by trying to attack the mobber is very low. Such results may be, according to Leymann [3], related to the functioning of institutions that control jobs in each country. The author proved that in countries such as Norway, where there is a high awareness of the labor law and there are many institutions dealing with the issues of work occurrences, citizens more often report their negative experiences to state authorities. Therefore, it can be concluded that the results obtained in the present study regarding the frequency of addressing victims of mobbing to institutions, in order to obtain assistance, are related to the determinants of the social and legal system in Poland.

The relationship between the experience of mobbing and attempts at self-defense by trying to attack the mobber was also weak. People experiencing mobbing defend themselves by trying to defuse the situation and being passive, but not by aggressive methods or by acting against the mobber. The results obtained by Lutgen-Sandvik [8] who emphasized that victims trying to come to an agreement with the mobber or openly opposing his/her behavior over time tend to use passive ways of dealing with mobbing, avoid being in his/her presence and eventually resign from work.

\section{CONCLUSIONS}

This knowledge is very important for courts and institutions helping mobbing victims. Data from the Statistical Information Handbook of Justice shows that in 2017, out of the 813 cases submitted to courts of first instance that concerned mobbing, discrimination, or sexual harassment in the workplace, only 42 were considered in full or in part. Thus, mobbing is a social problem whose significance can be diminished in the social consciousness due to the misunderstanding of its nature.

The literature on the subject indicates that the issue of mobbing can hardly be described, researched or understood [5]. Many important mechanisms remain unidentified and only detailed research makes it possible to put together the elements of current knowledge in this area. Leka and Jain [10] remarked that the "extrapolation of the effects of psychosocial working conditions on health is difficult on a global scale due to the lack of data." The interest in mobbing in the scientific community, along with expanding knowledge in this area, translates into practical implications. The authors point to the importance of research exploring the issue of mobbing, including for the implementation of activities aimed at preventing its negative effects [2]. Understanding both the dynamics of this phenomenon and the impact on victims is critical to implementing preventive measures.

The research described in this article is part of the exploration of this phenomenon and the identification of knowledge that can be translated into a practical area. The obtained results made it possible to present the problem of mobbing from 3 main perspectives, i.e., the coexistence of its manifestations, the relationship of individual manifestations with victims' reactions, and the relationship between the manifestations of this phenomenon, victims' reactions and the coping methods that are used. The conducted research serves to fill the existing gaps in literature and enables a better understanding of the problem, especially in the context of the behavior displayed by the victims. It is an innovative approach, introducing a significant amount of new knowledge into literature.

\section{REFERENCES}

1. Lorenz K. Tak zwane zło. Warszawa: Państwowy Instytut Wydawniczy; 1996.

2. Juvonen J, Graham S, editors. Peer harassment in school: The plight of the vulnerable and victimized. Guilford Press; 2001.

3. Leymann H. Mobbing and psychological terror at workplaces. Violence Victims. 1990;5(2):119-126.

4. Davenport N, Schwartz RD, Elliott GP. Mobbing: Emotional abuse in the American workplace. Civil Society Pub; 1999.

5. Zapf D, Einarsen S. Mobbing at Work: Escalated Conflicts in Organizations. In: Fox S, Spector PE, editors. Counterproductive work behavior: Investigations of actors and targets. American Psychological Association; 2005. p. $237-$ 270. https://doi.org/10.1037/10893-010.

6. Rayner C, Hoel H, Cooper CL. Bullying at work: What we know, who is to blame and what can we do. London: Taylor Francis; 2002.

7. Keashly L, Neuman JH. Faculty experiences with bullying in higher education: Causes, consequences, and management. Admin Theory Praxis. 2010;32(1):48-70. 
8. Lutgen-Sandvik P. Take this job and...: Quitting and other forms of resistance to workplace bullying. Commun Monogr. 2006;73(4):406-433.

9. Drabek M, Merecz D, Mościcka A. Mobbing - szczególny rodzaj zagrożenia w miejscu pracy. Med Pr. 2008:223-234.

10. Leka S, Jain A. Health impact of psychosocial hazards at work: an overview. World Health Organization; 2010. p. 100.

11. Batarowski H. Analiza potencjalnych czynników, wywołujących stres u pracowników. Gdańsk: Inspektorat Pracy. Stres w pracy; 2008.

12. Ostrowska MA, Michcik A. Mobbing - istota, przyczyny, przeciwdziałanie. Bezpieczeństwo Pracy: Nauka i praktyka. 2014:8-11.

13. Sidor-Rządkowska M. Mobbing - zagrożenie dla firmy i pracowników. Zarządzanie Zasobami Ludzkimi. 2003;2:77-85.

14. Izydorczyk A, Kęsa A. Mobbing w miejscu pracy jako przejaw patologii w procesie zarządzania. Zeszyty Naukowe Politechniki Łódzkiej, Organizacja i Zarzadzanie. 2015;1202(61):77-104.

15. Gamian-Wilk M, Grzesiuk L. Mobbing w miejscu pracy. Przegląd wyników badań związanych z przejawami mobbingu, genezą i konsekwencjami. Psychologia Społeczna. 2016;11(3):244-254.

16. Hirigoyen MF. Molestowanie w pracy. Poznań: Wydawnictwo W drodze; 2003.

17. Einarsen S, Hoel H, Cooper C, editors. Bullying and emotional abuse in the workplace: International perspectives in research and practice. CRC Press; 2002.

18. Grzesiuk L. Mobbing w miejscu pracy - czynniki ryzyka i konsekwencje. Zdrowie i choroba. Problemy teorii, diagnozy i praktyki. 2008:227-274.

19. Nielsen MB, Einarsen S. Outcomes of exposure to workplace bullying: A meta-analytic review. Work Stress. 2012;26(4):309-332.

20. Mościcka-Teske A, Drabek M, Pyżalski J. Doświadczanie mobbingu i wrogich zachowań w miejscu pracy a występowanie objawów wypalenia zawodowego u nauczycieli. Med Pr. 2014;65(4):535-542. https://doi. org/10.13075/mp.5893.00017.

21. Wysocki S. Przyczyny mobbingu oraz zapobieganie mobbingowi w organizacji - badania w przedsiębiorstwie komunikacyjnym. Nauki Społeczne. 2013;2(08):194-209.

22. Gamian-Wilk M, Zimoń-Dubowik B. Bierność jako strategia radzenia sobie $\mathrm{z}$ mobbingiem $\mathrm{w}$ miejscu pracy. Bierność społeczna: Studia interdyscyplinarne. 2008:315-329.
23. Rayner C, Keashly L. Bullying at work: a perspective from Britain and North America. In: Counterproductive work behavior: Investigations of actors and targets. Washington: 2005: p. 271-296.

24. Piątkowska A. Mobbing w miejscu pracy jako przyczyna rozwiązania przez pracownika umowy o pracę bez wypowiedzenia. Pracownik i Pracodawca. 2015;1(1): 118-30.

25. Szonert-Rzepecka D. Sytuacje trudne w środowisku pracy - raport z badań dotyczących sposobów radzenia sobie ze stresem wśród pracowników małych i średnich przedsiębiorstw województwa łódzkiego. Zarządzanie stresem. Część I. 2013.

26. Warszewska-Makuch M. Zjawisko mobbingu wśród nauczycieli. Bezpieczeństwo Pracy: Nauka i praktyka. 2008;5:6-9.

27. Einarsen S, Mikkelsen EG. Individual effects of exposure to bullying at work. Bullying and emotional abuse in the workplace: International perspectives in research and practice. 2003;6.

28. Strauss S, Espeland P. Sexual harassment and teens: a program for positive change: case studies, activities, questionnaires, laws, guidelines, policies, procedures, resources, and more. Free Spirit Pub; 1992.

29. Szymańska A. Wykorzystanie analizy skupień metodą data mining do wykreślania profili osób badanych w badaniach psychologicznych [Using cluster analysis in the data mining method to draw profiles of participants surveyed in psychological research]. Studia Psychologiczne. 2017;55(1):25-40.

30. Konarski R. Modele równań strukturalnych [Structural equation models]. Warsaw: PWN; 2009. Polish.

31. Hair JF, Black B, Babin B, Anderson R, Tatham R. Multivariate data analysis. 6th ed. 2006.

32. Infor [Internet]. Zagrożenia psychospołeczne w miejscu pracy - raport "Bezpieczeństwo pracy w Polsce 2019" [cited 2020 Mar 2]. Available from: https://www. infor.pl/prawo/praca/mobbing/3070057,Zagrozenia-psychospoleczne-w-miejscu-pracy-raport-Bezpieczenstwo-pracy-w-Polsce-2019.html.

33. Sedlak \& Sedlak [Internet]. Mobbing - podsumowanie najważniejszych informacji dla pracodawcy, cz. I [cited 2020 Mar 2]. Available from: https://badaniahr.pl/ biblioteka/mobbing-podsumowanie-najwazniejszych-informacji-dla-pracodawcy-cz-i/70.

This work is available in Open Access model and licensed under a Creative Commons Attribution-NonCommercial 3.0 Poland License - http://creativecommons.org/licenses/by-nc/3.0/pl/deed.en. 